\title{
The N-Terminal Domain of PMTV TGB1 Movement Protein Is Required for Nucleolar Localization, Microtubule Association, and Long-Distance Movement
}

\author{
Kathryn M. Wright, ${ }^{1}$ Graham H. Cowan, ${ }^{1}$ Nina I. Lukhovitskaya, ${ }^{2}$ Jens Tilsner, ${ }^{1}$ Alison G. Roberts, ${ }^{1}$ \\ Eugene I. Savenkov, ${ }^{2}$ and Lesley Torrance ${ }^{1}$ \\ ${ }^{1}$ Plant Pathology Programme, Scottish Crop Research Institute, Invergowrie, Dundee DD2 5DA, U.K.; ${ }^{2}$ Department of Plant \\ Biology and Forest Genetics, Uppsala BioCenter SLU, Box 7080, SE-750 07 Uppsala, Sweden
}

Submitted 7 May 2010. Accepted 11 June 2010.

\begin{abstract}
The triple-gene-block (TGB)1 protein of Potato mop-top virus (PMTV) was fused to fluorescent proteins and expressed in epidermal cells of Nicotiana benthamiana under the control of the $35 \mathrm{~S}$ promoter. TGB1 fluorescence was observed in the cytoplasm, nucleus, and nucleolus and occasionally associated with microtubules. When expressed from a modified virus (PMTV.YFP-TGB1) which formed local lesions but was not competent for systemic movement, yellow fluorescent protein (YFP)-TGB1 labeled plasmodesmata in cells at the leading edge of the lesion and plasmodesmata, microtubules, nuclei, and nucleoli in cells immediately behind the leading edge. Deletion of 84 amino acids from the N-terminus of unlabeled TGB1 within the PMTV genome abolished movement of viral RNA to noninoculated leaves. When the same deletion was introduced into PMTV.YFP-TGB1, labeling of microtubules and nucleoli was abolished. The N-terminal 84 amino acids of TGB1 were fused to green fluorescent protein (GFP) and expressed in epidermal cells where GFP localized strongly to the nucleolus (not seen with unfused GFP), indicating that these amino acids contain a nucleolar localization signal; the fusion protein did not label microtubules. This is the first report of nucleolar and microtubule association of a TGB movement protein. The results suggest that PMTV TGB1 requires interaction with nuclear components and, possibly, microtubules for long-distance movement of viral RNA.
\end{abstract}

Potato mop-top virus (PMTV), the type species of the genus Pomovirus, has rod-shaped particles and a tripartite genome (Torrance 2008). Pomovirus spp. have recently been classified in the family Virgaviridae together with six other genera of tubular rod-shaped viruses, including the Hordeivirus and Pecluvirus spp. (Adams et al. 2009). The PMTV genome consists of three single-stranded RNAs, called here RNA1, RNA $^{\mathrm{TGB}}$ and RNA ${ }^{\mathrm{CP}}$ (Fig. 1A) (Torrance et al. 2009), which encode eight open reading frames (ORF), including three triple-gene-block (TGB) movement proteins (MPs) on RNA ${ }^{\mathrm{TGB}}$. TGB MPs act in a coordinated manner to facilitate cell-to-cell and long-distance virus movement. They are present in nine

Corresponding author: L. Torrance; E-mail: Lesley.Torrance@scri.ac.uk; Telephone: +44 1382 568525; Fax: +44 1382568578

* The $\boldsymbol{e}$-Xtra logo stands for "electronic extra" and indicates that a supplementary table and a supplementary movie are available online. genera of rod-shaped and filamentous viruses and two major classes have been distinguished: the hordei-like (class 1) and the potex-like (class 2) (Morozov and Solovyev 2003; VerchotLubicz 2005; Jackson et al. 2009). PMTV Pomovirus TGB proteins are considered to belong to the hordei-like or class 1 group, which also includes the TGB proteins of viruses in other genera within the Virgaviridae, the Hordeivirus spp. Barley stripe mosaic virus (BSMV) and Poa semi-latent virus (PSLV), and the Pecluvirus sp. Peanut clump virus (PCV).

Class 1 TGB1 proteins range in mass from 42 to $63 \mathrm{kDa}$ and have a domain structure with a variable $\mathrm{N}$-terminal half and a conserved C-terminal half which contains an NTPase/helicase domain that binds RNA in a cooperative manner (Bleykasten et al. 1996; Donald et al. 1997; Kalinina et al. 2001, 2002; Leshchiner et al. 2006). The N-terminal half comprises two structurally distinct subdomains, an N-terminal domain (NTD) and an internal domain (ID) that display sequence-nonspecific binding of single-stranded RNA in noncooperative and cooperative manners, respectively (Makarov et al. 2009). Both domains also bind double-stranded RNA. TGB1 is the major protein component in BSMV ribonucleoprotein (RNP) complexes isolated from infected barley tissues (Lim et al. 2008). All three TGB proteins are required for cell-to-cell movement, with TGB2 and TGB3 assisting targeting of TGB1 to plasmodesmata (PD) (Erhardt et al. 1999, 2000; Lawrence and Jackson 2001; Zamyatnin et al. 2004; Lim et al. 2008, 2009). Experiments with PMTV TGB1 fused to green fluorescent protein (GFP) indicate that TGB1 does not move cell to cell when expressed alone (Zamyatnin et al. 2004; Lim et al. 2009). Although it seems likely that the TGB proteins interact to facilitate cell-to-cell movement of the viral ribonucleoprotein (vRNP), there is little experimental evidence of molecular interactions. Homologous interactions have been found between the TGB1 proteins of PMTV, PSLV, and BSMV (Cowan et al. 2002; Leshchiner et al. 2006; Lim et al. 2008), and heterologous interactions occur between BSMV TGB1 and TGB3, BSMV TGB2 and TGB3 (Lim et al. 2008), and PMTV TGB2 and TGB3 (Cowan et al. 2002). In addition, a heterologous interaction has been found between PMTV TGB1 and the protein produced on translational readthrough (RT) of the stop codon of the coat protein (CP) (CP-RT), an association which is thought to be important in systemic transport of virus particles (Torrance et al. 2009).

There is little information on subcellular localizations of class 1 TGB1 proteins. A reporter virus, constructed by fusing GFP to the N-terminus of BSMV TGB1, moved cell to cell and was competent for systemic infection of Nicotiana bentha- 
miana and barley (Lawrence and Jackson 2001). Fluorescent microscopy revealed that GFP localized to PD at the leading edge of infection and was associated with the endoplasmic reticulum (ER) and perinuclear membranes. In mutant clones where the expression of TGB2 or TGB3 was inhibited, labeling of the plasma membrane and PD was abolished but not the association with the ER (Lawrence and Jackson 2001). Previously, when GFP was fused to the N-terminus of PMTV TGB1 (GFP-TGB1) and expressed in epidermal cells under the control of the $35 \mathrm{~S}$ promoter, fluorescence was seen in the nucleus and cytoplasm. When GFP-TGB1 was expressed together with TGB2 and TGB3, GFP-TGB1 was directed to PD and transported into neighboring cells (Zamyatnin et al. 2004). In the same work, a reporter clone of PMTV expressing GFP-TGB1 was shown to be competent for cell-to-cell movement and formed spreading lesions, indicating that the fusion protein could function in intercellular movement (Zamyatnin et al. 2004). The aim of this work was to investigate in more detail the localizations and interactions of PMTV TGB1 during the course of infection. The data presented reveal a previously un-

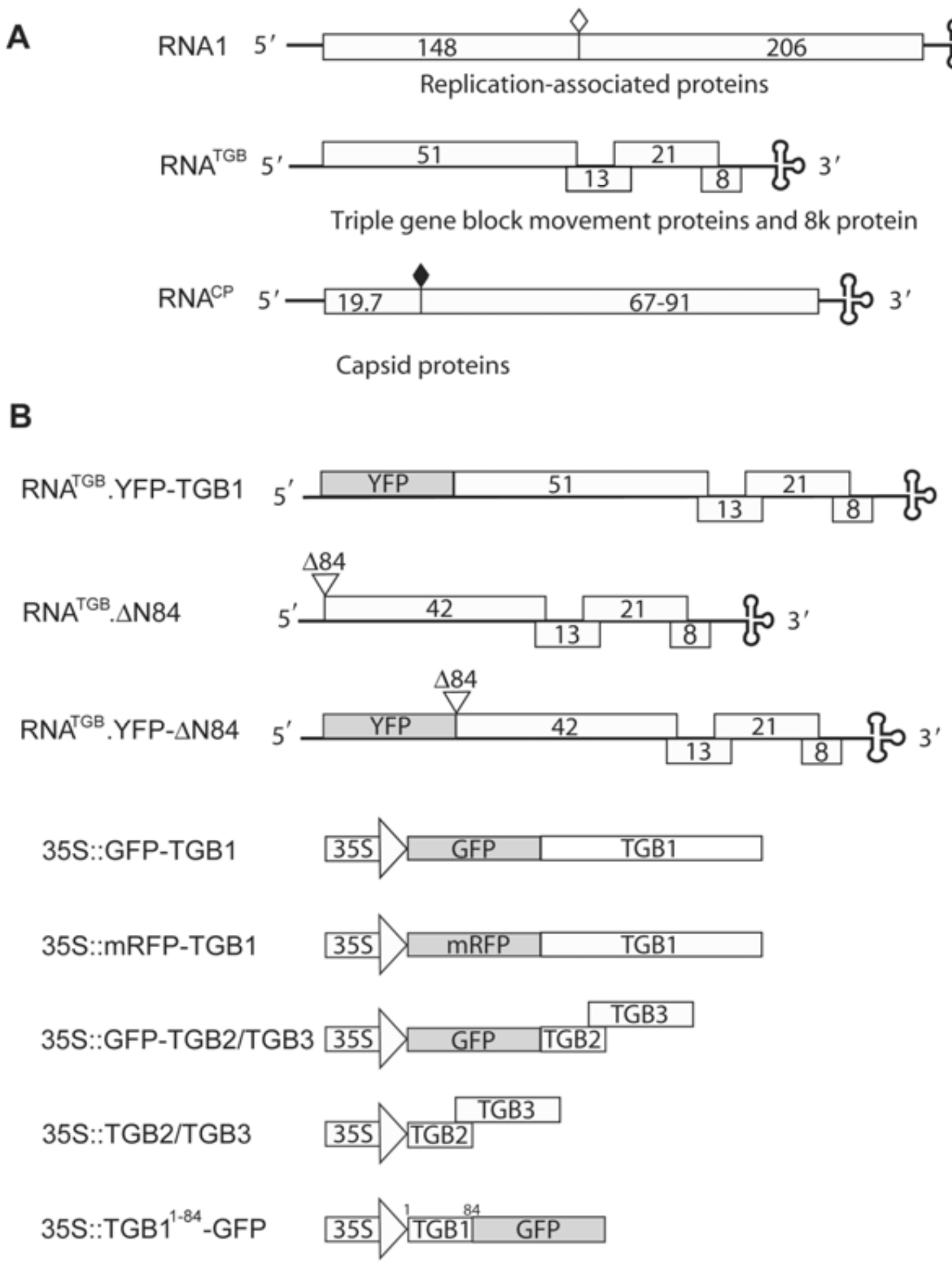

Fig. 1. A, Genome organization of Potato mop-top virus (PMTV) and B, constructs used in this study. Readthrough stop codons in RNA1 and RNA ${ }^{\mathrm{CP}}$ are indicated by diamonds and the sizes of the translation products are given in kilodaltons. 
reported association of TGB1 with the nucleolus and show that the N-terminus of TGB1 has a function in viral long-distance movement that is distinct from its role in local cell-to-cell trafficking of vRNPs and is not linked to interaction with CPRT.

\section{RESULTS}

Expression of fluorescent TGB1 fusions in epidermal cells.

The localization of 35S::monomeric red fluorescent protein (mRFP)-TGB1 and 35S::GFP-TGB1 (Fig. 1B) in epidermal cells was examined to confirm the GFP localizations previously reported (Zamyatnin et al. 2004). In all cases, identical results were obtained regardless of the fluorescent protein used. In these experiments, similar to Zamyatnin and associates (2004), diffuse fluorescence was observed in the nucleus and cytoplasm but did not spread to neighboring cells; PD were not labeled (Fig. 2A). In addition, fluorescence accumulated in the nucleolus (Fig. 2B). Occasionally, GFP- or mRFP-TGB1 labeled microtubules (data not shown). The localization of mRFP-TGB1 was then examined when coexpressed with TGB2 and TGB3 from a bicistronic plasmid expressing GFP-TGB2/TGB3 (Fig. 1B) (Tilsner et al. 2010). Cells expressing both plasmids were examined and no association was observed between mRFPTGB1 and GFP-TGB2 (Fig. 2C and D) and neither fluorescent fusion protein moved to neighboring cells. In marked contrast, when 35S::GFP-TGB1 (or 35S::mRFP-TGB1) was co-bombarded with 35S::TGB2/TGB3 (i.e., unlabeled TGB2) (Fig. 1B), GFP-TGB1 labeled PD at the cell wall and fluorescence was observed in adjacent cells (Fig. 2E). Green fluorescence also accumulated in the nucleolus (Fig. 2F). Neither TGB2 nor TGB3 accumulated in the nucleus or nucleolus and the presence of TGB2 and TGB3 did not noticeably affect TGB1 microtubule association. Therefore, TGB1 associates with the nucleolus but is also directed to PD in the presence of TGB2 and TGB3, and the three TGB proteins can functionally interact without fulllength viral RNA. The bicistronic GFP-TGB2/TGB3 construct did not allow TGB1 targeting to PD, suggesting that the presence of GFP fused to the N-terminus of TGB2 may interfere with the interaction between TGB1 and TGB2 (note that GFP fused to the N-terminus of TGB2 does not interfere with targeting of TGB2 to PD by TGB3).

\section{Yellow fluorescent protein-TGB1 associates with PD, motile bodies, the nucleolus and microtubules when expressed from a virus reporter clone.}

Zamyatnin and associates (2004) have previously reported that a modified PMTV encoding GFP-fused TGB1 is infectious and moves cell to cell but they did not analyze the subcellular localization of the virus-expressed GFP-TGB1. In order to investigate whether TGB1 associates with nucleolus and microtubules in the course of infection, yellow fluorescent protein (YFP)-TGB1 was expressed from the PMTV genome. Following inoculation with infectious transcripts of PMTV RNA1 and RNA ${ }^{\mathrm{TGB}}$.YFP-TGB1 (Fig. 1B; collectively referred to as PMTV.YFP-TGB1), a fluorescent lesion formed as the virus moved cell to cell. The subcellular localization of YFPTGB1 was similar either in the presence or absence of PMTV $\mathrm{RNA}^{\mathrm{CP}}$ although, in the presence of $\mathrm{CP}$, the resulting lesions were smaller in size. Long-distance movement of the fluorescent virus out of the inoculated leaf was not observed in either case. The following description refers to lesions formed in the absence of RNA ${ }^{\mathrm{CP}}$ due to their larger size.

At the leading edge of a PMTV.YFP-TGB1 lesion, YFPTGB1 localized to punctate structures in the wall and to the cytoplasm (Fig. 3A). These structures were confirmed to be PD by colocalization with aniline-blue-stained callose (Fig. 3B to D), although it was evident that not all PD accumulated the protein. Behind the leading edge of the lesion, small motile bodies were seen within the cytoplasm moving in association with the ER network (Fig. 3E through H; Supplementary Movie). Within two to four cells of the visible lesion edge, YFP-TGB1 fluorescence accumulated on microtubules (Fig. 3I) and remained associated with microtubules (Fig. 3J) and PD (Fig. 3K) toward the center of the lesion.

Examination of nuclei in cells at the leading edge of the infection revealed that YFP-TGB1 was located in the cytoplasm surrounding the nucleus but was excluded from the nucleoplasm (Fig. 3L). Within two to three cells of the leading edge, YFP-TGB1 also entered the nucleoplasm and accumulated in and around the nucleolus (Fig. 3M). The nucleolar accumulation was confirmed by colocalization with transiently expressed, mRFP-labeled Arabidopsis fibrillarin 2 (AtFib2-mRFP), a marker for nucleoli and Cajal bodies (Barneche et al. 2000)

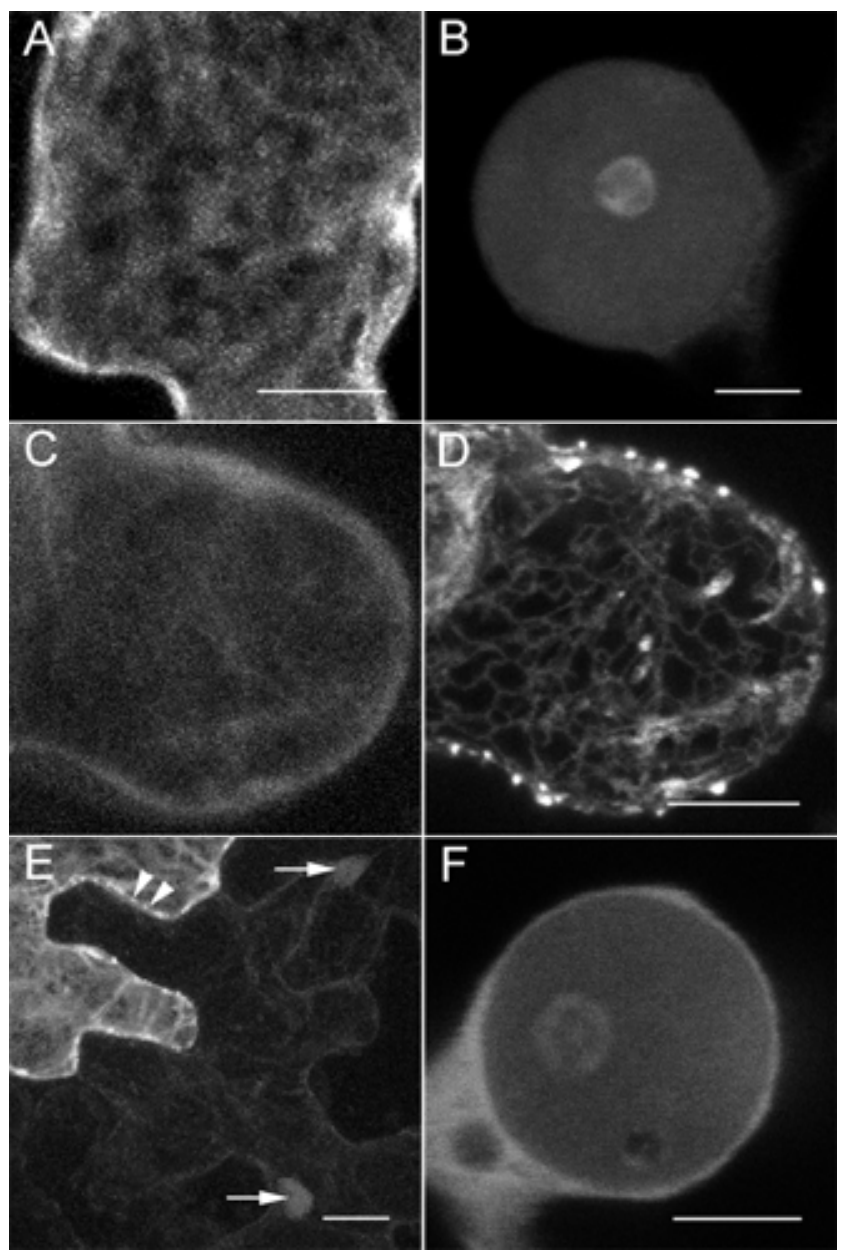

Fig. 2. Subcellular localization of 35S-expressed green fluorescent protein (GFP)- or monomeric red fluorescent protein (mRFP)-triple-geneblock (TGB)1 in Nicotiana benthamiana epidermal cells. A, Image showing cytosolic expression of 35S::mRFP-TGB1. B, Single confocal section showing expression of $35 \mathrm{~S}:$ GFP-TGB1 with localization in the nucleus and nucleolus. $\mathbf{C}$ and $\mathbf{D}$, Coexpression in a cell of 35S::mRFPTGB1 and 35S::GFP-TGB2/TGB3 showing $\mathbf{C}$, cytosolic mRFP-TGB1 and $\mathbf{D}$, the association of GFP-TGB2 with the endoplasmic reticulum and plasmodesmata (PD) (darts). E, Single confocal section showing the association of TGB1 with PD (darts) and cell-to-cell movement in epidermal cells (arrows indicate nuclear labeling in adjacent cells) coexpressing 35S::GFP-TGB1 and unlabeled bicistronic 35S::TGB2/TGB3. F, Single confocal section showing GFP-TGB1 in the nucleus and nucleolus of an epidermal cell coexpressing bicistronic 35S::GFP-TGB1 and unlabeled 35S::TGB2/TGB3. Bar $=\mathrm{A}, 10 \mu \mathrm{m} ; \mathrm{B}, 5 \mu \mathrm{m}$; C and D, 10 $\mu \mathrm{m} ; \mathrm{E}, 20 \mu \mathrm{m}$; F, $5 \mu \mathrm{m}$. 


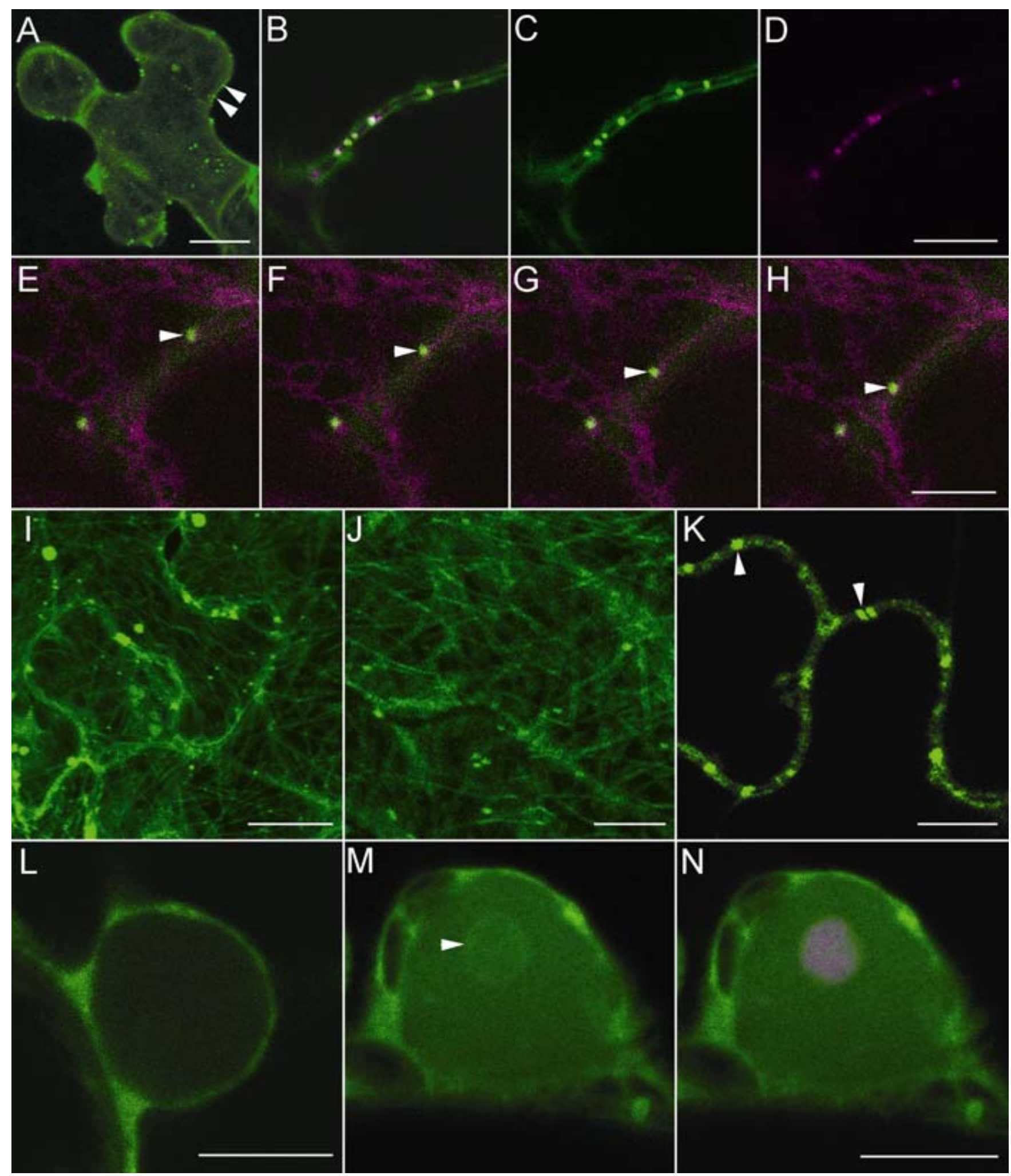

Fig. 3. Subcellular localization of yellow fluorescent protein (YFP)-triple-gene-block (TGB)1 in Potato mop-top virus (PMTV)-infected Nicotiana benthamiana epidermal tissue. A, Image taken at the leading edge of a YFP-TGB1 lesion showing the localization of YFP-TGB1 to plasmodesmata (PD) (darts) and the cytoplasm. B, Single overlaid confocal section illustrating C, YFP-TGB1 (green) located in punctate structures in the cell wall which colocalize with $\mathbf{D}$, aniline-blue-stained callose (magenta) in PD. $\mathbf{E}$ to $\mathbf{H}$, Time series showing motile body (dart) of YFP-TGB1 (green) moving along the tubular network of an endoplasmic reticulum-green fluorescent protein plant (magenta). Sections were collected $1.164 \mathrm{~s}$ apart. I, Image taken two to three cells behind the visible leading edge of a lesion showing accumulation on microtubules. J, Toward the center of a lesion, YFP-TGB1 remains associated with microtubules. K, Single confocal section shows that YFP-TGB1 remains associated with PD (darts) toward the center of a lesion. L, Single confocal section taken through a nucleus at the leading edge of a lesion showing the accumulation of YFP-TGB1 in the cytoplasm and its exclusion from the nucleus. M, Single confocal section taken through a nucleus within the region of cells illustrated in I, showing the accumulation of YFP-TGB1 (green) in the nucleoplasm and nucleolus, sometimes accumulating in a ring (dart) around the nucleolus. N, The nucleolus can be distinguished by the accumulation of monomeric red fluorescent protein-labeled Arabidopsis fibrillarin 2 (magenta). Bar = A, $50 \mu \mathrm{m}$; B to D, $10 \mu \mathrm{m} ; \mathrm{E}$ to H, $5 \mu \mathrm{m} ; \mathrm{I}, 50 \mu \mathrm{m}$; J to N, $10 \mu \mathrm{m}$. 
(Fig. 3N). Moreover, fluorescence did not fade at the center of lesions and association with the nucleolus, microtubules, and PD was still visible.

\section{Association with microtubules is not needed for virus cell-to-cell movement.}

The role of microtubules in the infection process was investigated further. Cells in which YFP-TGB1 associated with microtubules were imaged (Fig. 4A) and then reimaged after approximately $16 \mathrm{~h}$. After this time, the YFP-TGB1 was still associated with the microtubules but the microtubule network had rearranged (Fig. 4B). Expanding YFP-TGB1 lesions on transgenic plants expressing a fusion of GFP to Arabidopsis $\alpha$ tubulin (TUA-GFP) were infiltrated with the microtubuledisrupting inhibitor colchicine and imaged before (Fig. 4C and D) and after (Fig. 4E and F) overnight incubation. Colchicine treatment disrupted the microtubules, including those decorated with YFP-TGB1, but neither colchicine nor oryzalin (another microtubule-disrupting drug) had any significant effect on lesion expansion over $48 \mathrm{~h}(t$ test; $P>0.2$ ) (Table 1$)$. Hence, microtubules appear not to be required for cell-to-cell movement of PMTV.
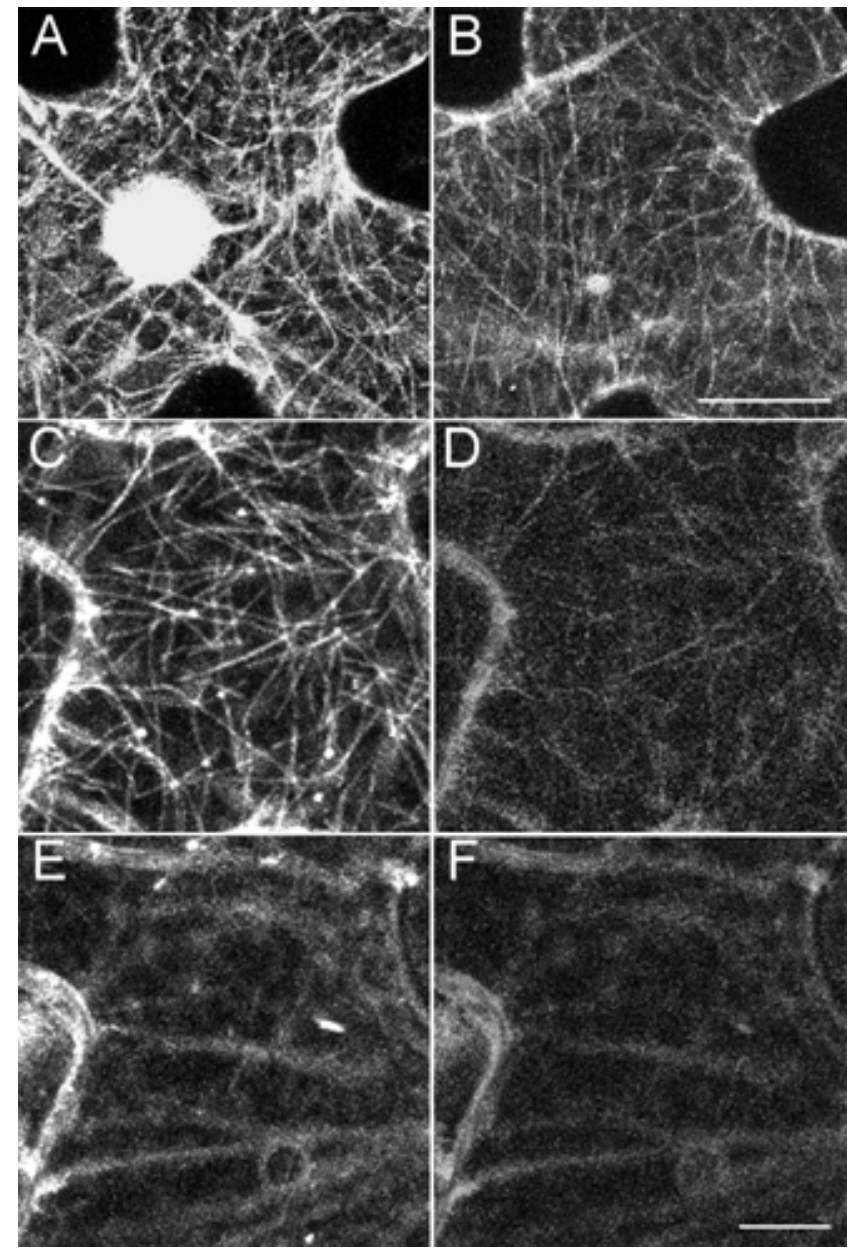

Fig. 4. Association of triple-gene-block (TGB) 1 with microtubules. A, At time 0 , yellow fluorescent protein (YFP)-TGB1 associates with microtubules in a leaf of Nicotiana benthamiana. B, After overnight incubation ( $22 \mathrm{~h} 55$ $\min$ ), the protein is still seen in association with microtubules but the network has been rearranged. Leaf of Arabidopsis $\alpha$-tubulin-green fluorescent protein transgenic plant immediately after treatment with $500 \mu \mathrm{M}$ colchicine, showing $\mathbf{C}$, the association of YFP-TGB1 with $\mathbf{D}$, an intact microtubule network. Following overnight incubation, E, YFP-TGB1 is located in the cytoplasm following the complete disruption of $\mathbf{F}$, the microtubule network. Bar $=\mathrm{A}$ and $\mathrm{B}, 20 \mu \mathrm{m} ; \mathrm{C}$ to F, $10 \mu \mathrm{m}$.
Free N-terminus of TGB1 is needed

for systemic movement but not for cell-to-cell movement.

Although PMTV RNAs move cell to cell when the $T G B 1$ gene within the viral genome is fused N-terminally to a fluorescent protein, the tagged virus never moved systemically. It is possible that the presence of GFP inhibits long-distance movement due to the increased size of the fusion protein, or by blocking an important domain at the $\mathrm{N}$ terminus of TGB1. To investigate these possibilities, a mutant $\mathrm{RNA}^{\mathrm{TGB}}$ clone was created which contained a deletion in the N-terminal part of the TGB1 ORF in the recently identified NTD domain (Makarov et al. 2009). This deletion resulted in the expression of an 84amino-acid (aa) N-terminally truncated TGB1 $(\Delta \mathrm{N} 84)$ (Fig. 1B) with almost complete deletion of the NTD. Northern blot and enzyme-linked immunosorbent assay tests revealed that the N-terminal deletion mutant accumulated in inoculated leaves (Fig. 5A and B) but viral RNAs failed to move systemically to the upper leaves, indicating that the $\mathrm{N}$ terminus of the TGB1 is not needed for virus cell-to-cell movement but is indispensable for long-distance movement of all three RNA species.

We also investigated whether $\mathrm{N}$-terminal truncation affected TGB1 self-interaction or interaction with the CP-RT domain, an interaction previously shown to be correlated with the longdistance movement of RNA-CP (Torrance et al. 2009). Analyses of protein interactions in the yeast two-hybrid assay revealed self-interactions between CP-RT, TGB1, and $\triangle \mathrm{N} 84$ (Fig. 5C). Additionally, both wild-type TGB1 and the $\Delta$ N84 deletion mutant fused to the activation domain interacted with CP-RT fused to the DNA-binding domain (Fig. 5C). Therefore, deletion of the N-terminal amino acids had no effect on the homologous interaction of TGB1 or the interaction with the CP-RT domain.

\section{The N-terminus of TGB1 is needed}

\section{for microtubule and nucleolar targeting.}

To visualize cell-to-cell movement of the TGB1 N-terminal deletion mutant, the TGBl gene in the PMTV RNA ${ }^{\mathrm{TGB}}$ clone was substituted for a YFP- $\triangle \mathrm{N} 84$ fusion. PMTV.YFP- $\Delta N 84$ formed discrete yellow fluorescent lesions (Fig. 6A) but did not move systemically. YFP- $\triangle \mathrm{N} 84$ accumulated in the cytoplasm and in punctate structures in the cell wall at the leading edge of lesions (Fig. 6B) and remained there further into the lesion but, in contrast to YFP-TGB1, the YFP- $\Delta$ N84 did not accumulate on the microtubules (Fig. 6C). The punctate structures were confirmed by colocalization with aniline blue to be PD (Fig. 6D and E). Examination of the nuclei indicated that, although YFP- $\triangle \mathrm{N} 84$ accumulated in the nucleoplasm, it was excluded from the nucleoli (Fig. 6F).

To determine the role of the TGB1 N-terminus in microtubule association and nucleolar accumulation, we created a GFP fusion of the $84 \mathrm{~N}$-terminal amino acids alone (TGB $1^{1-84}$ GFP), and examined its subcellular localization. TGB1 $1^{1-84}-\mathrm{GFP}$ was enriched in the nucleolus and labeled it more strongly than the nucleoplasm (Fig. $6 \mathrm{H}$ and I), in marked contrast with unfused GFP, which was completely excluded from the nucleolus (Fig. 6G). TGB $1^{1-84}$-GFP was not associated with microtubules. Therefore, the N-terminus of TGB1 is responsible for nucleolar association of the protein.

Table 1. Effects of cytoskeletal inhibitors on Potato mop-top virus lesion size

\begin{tabular}{lcccc}
\hline & \multicolumn{2}{c}{ Mean \pm standard error $\left(\ln \left[\mathbf{m m}^{2}\right]\right)(\boldsymbol{n})$} & & \\
\cline { 2 - 3 } Inhibitor & Control & Treatment & & $\boldsymbol{t}$ \\
\hline Colchicine & $0.97 \pm 0.17(5)$ & $0.73 \pm 0.16(6)$ & 2.26 & 0.35 \\
Oryzalin & $0.57 \pm 0.18(9)$ & $0.34 \pm 0.05(15)$ & 2.26 & 0.25 \\
\hline
\end{tabular}




\section{DISCUSSION}

The results show that, when TGB1 is expressed from a $35 \mathrm{~S}$ promoter, it is found throughout the nucleus and cytoplasm, accumulates in the nucleolus, and occasionally labels microtubules. These results confirm a previous report (Zamyatnin et al. 2004); moreover, the nucleolar and microtubule localiza- tions are new findings and the first report of a TGB protein being associated with either of these organelles. Similar to findings with BSMV and PSLV TGB1s (Solovyev et al. 2000; Zamyatnin et al. 2002; Lim et al. 2009), co-expression of TGB2 and TGB3 (in the absence of vRNA) directed GFP- or mRFPTGB1 to PD, where the protein accumulated and moved into neighboring cells. In addition, TGB1 still occurred in the cyto-
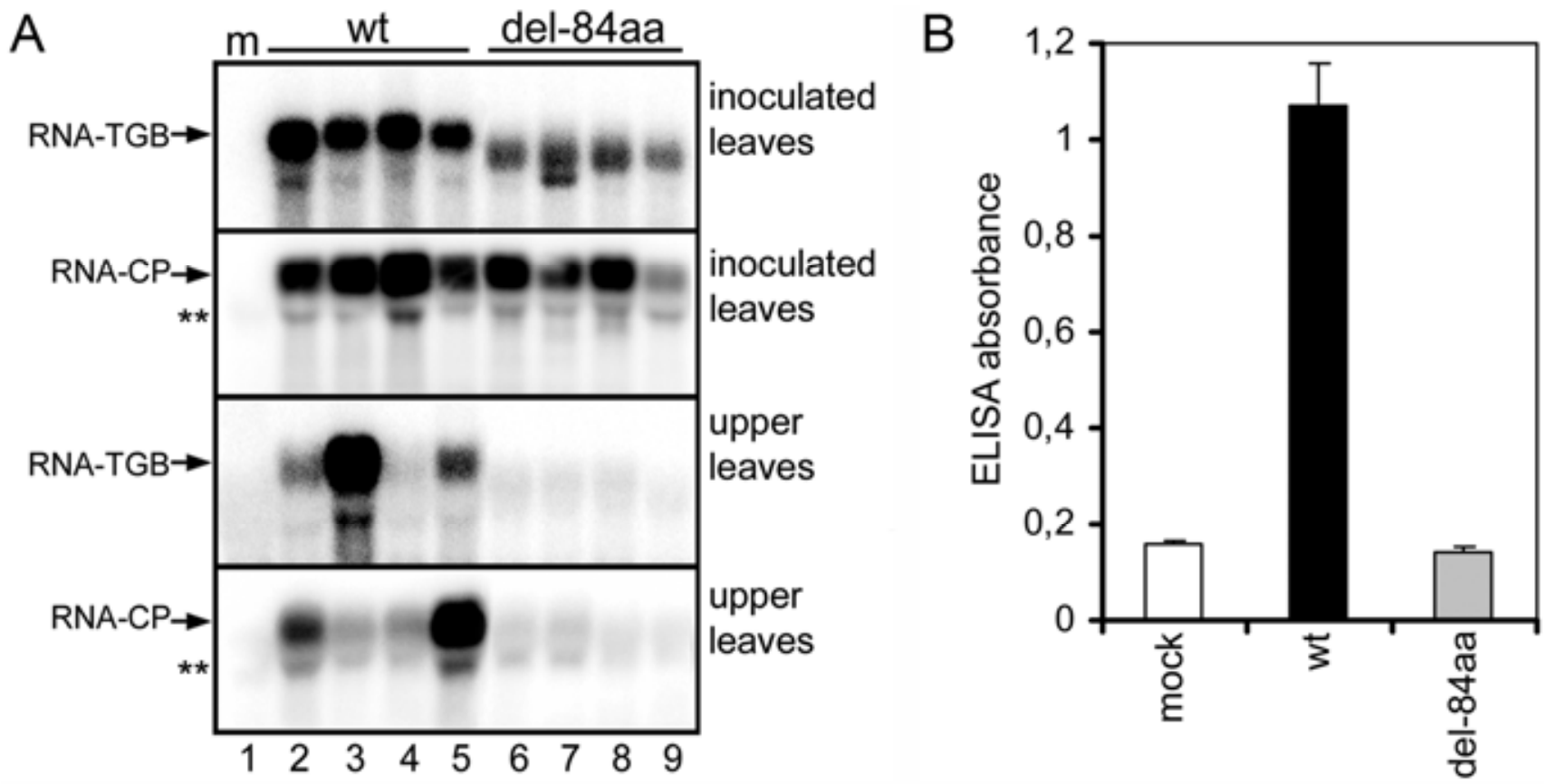

C

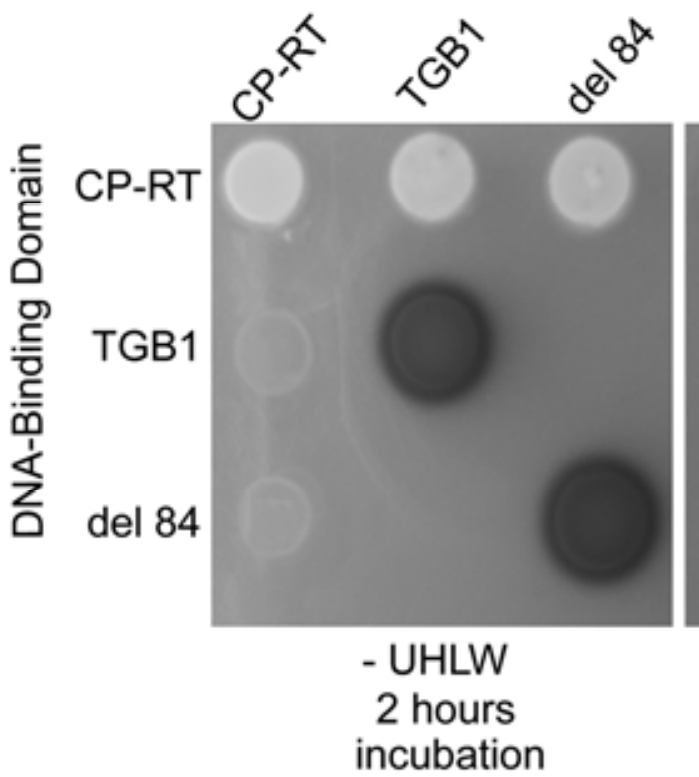

\section{Activation Domain}
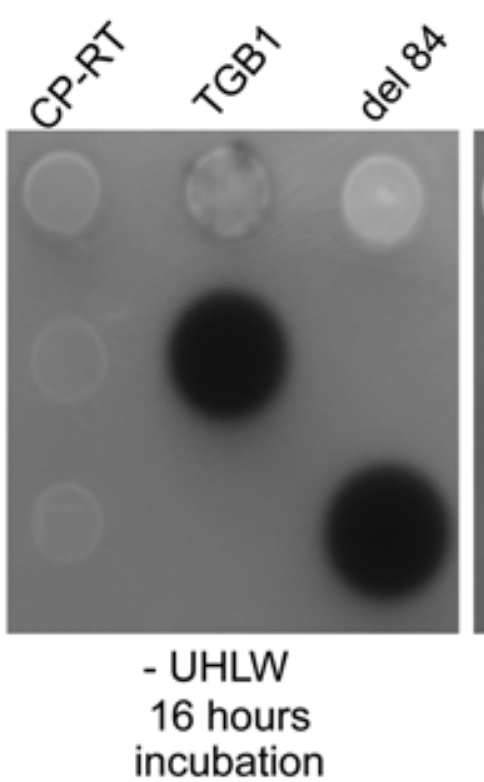

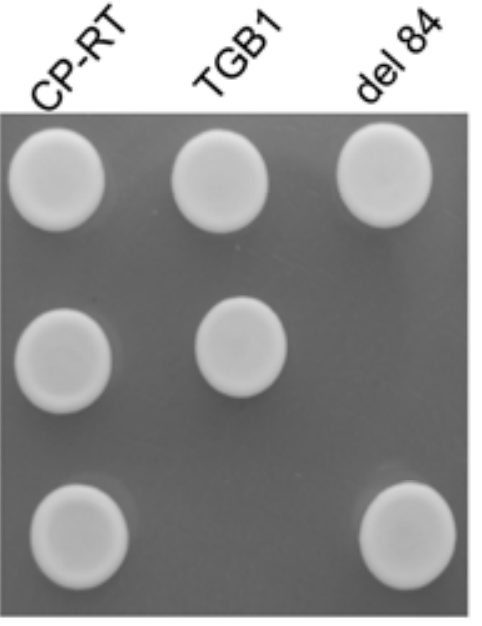

- ULW

Fig. 5. Effects of N-terminal deletion in triple-gene-block (TGB)1 protein on the accumulation, cell-to-cell, and long-distance movement of viral RNAs, and interaction with readthrough of the stop codon of the coat protein (CP-RT). A, Northern blot analysis of progeny viral RNAs accumulated in Nicotiana benthamiana plants inoculated with the mutant of RNA-TGB transcripts along with wild-type (wt) RNA 1 and RNA-CP transcripts. Total cellular RNA was extracted from inoculated leaves and upper noninoculated leaves 14 days postinoculation (dpi). The Northern blots were analyzed with Potato mop-top virus (PMTV)-TGB-specific and RNA-CP-specific riboprobes. Asterisks indicate nonspecific binding of the riboprobe to unknown RNA (**). Reproducible results were obtained in three experiments. B, Detection of PMTV CP by enzyme-linked immunosorbent assay as indicated by absorbance values at 405 nm. Plant extracts were prepared from upper noninoculated leaves 14 dpi. The means $(n=12)$ of background absorbance from mock inoculation (white bars) served as the control to which the wt virus and the mutants were compared (tinted bars). Above bars are standard errors of the means. C, CP-RT, TGB1, and del-N-TGB1 interactions assessed in yeast two-hybrid system. The wt or mutated PMTV sequences were fused to the LexA binding domain (cloned into pLex-N plasmid) or VP16 DNA activation domain (cloned into pVP16+ plasmid). Transformants were selected for protein interactions on medium lacking uracil, histidine, leucine, and tryptophan (-UHLW). Medium lacking uracil, leucine, and tryptophan (-ULW) selected for the input plasmids only. $\beta$-Galactosidase activity was assessed by agarose overlay assays at two time points ( 2 and $16 \mathrm{~h}$ of incubation at $\left.28^{\circ} \mathrm{C}\right)$. 
plasm and nucleus, and nucleolar and microtubule associations were unaffected by the TGB2/TGB3-assisted PD targeting. Mutational analysis by Zamyatnin and associates (2004) has implicated the PMTV TGB2 $\mathrm{C}$ terminus in interactions with TGB1. The fact that the GFP-TGB2/TGB3 construct, with GFP fused to the TGB2 N-terminus, does not cause relocation of TGB1 to PD now indicates that the N-terminus of TGB2 may also play a role in the association with TGB1. PMTV TGB2 is a nonspecific RNA-binding protein (Cowan et al. 2002) and, for the homologous TGB2 protein of Potato virus $X$, Hsu and associates (2009) have shown that the entire tertiary protein structure rather than specific side chains are required for RNA binding. Perhaps interaction of PMTV TGB2 with TGB1 similarly requires the entire cytosolic surface of correctly folded TGB2.

YFP-TGB1 association with microtubules does not prevent rearrangement of the microtubule network or prevent its disruption by microtubule inhibitors. In contrast, association of Tobacco mosaic virus (TMV)-MP with microtubules results in

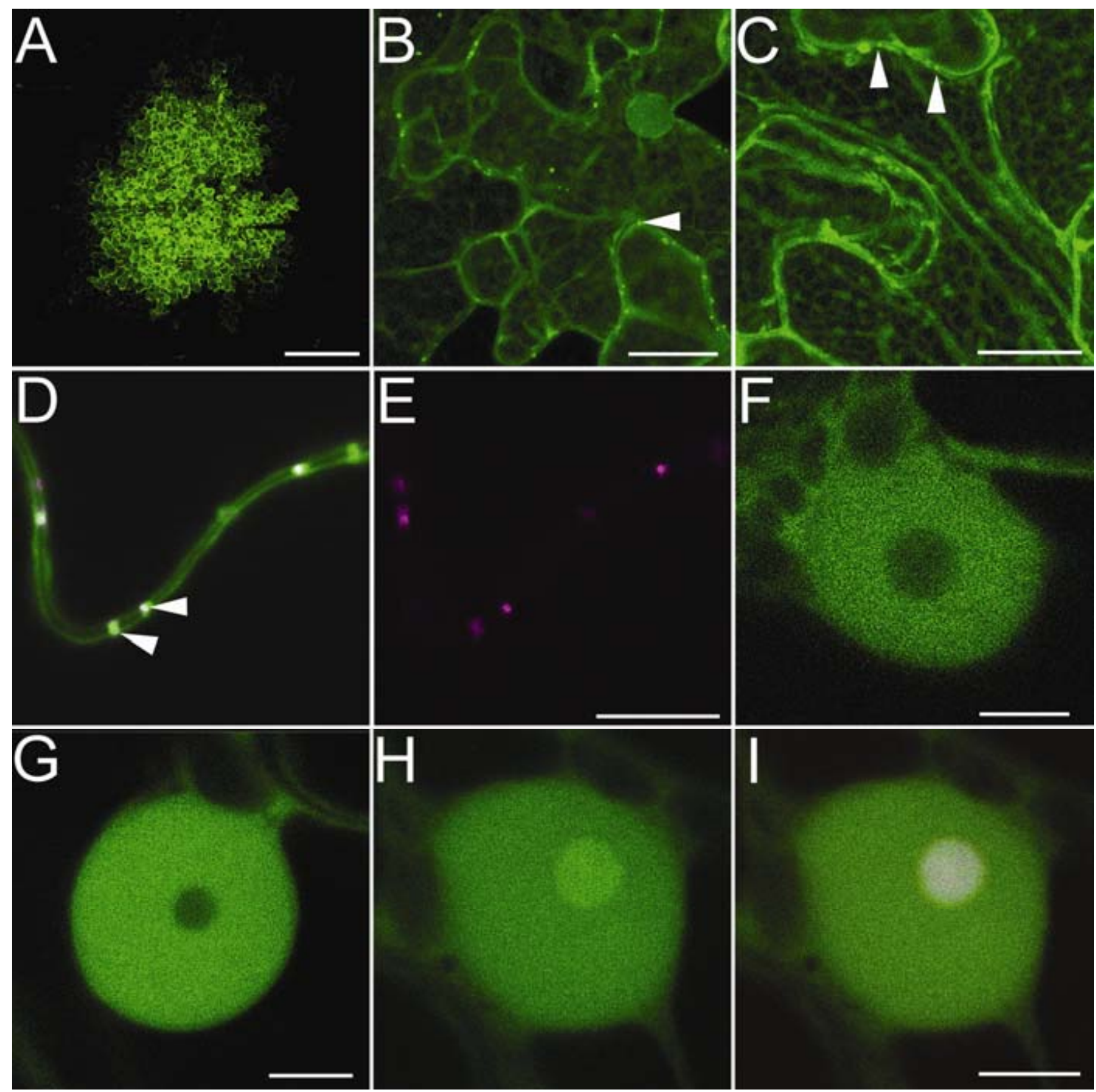

Fig. 6. Localizations of triple-gene-block (TGB)1 N-terminal deletion mutant and fragment in Nicotiana benthamiana epidermal cells. A, Appearance of Potato mop-top virus (PMTV)-yellow fluorescent protein (YFP)- $\Delta$ N84 fluorescence in a developing lesion 2 days postinoculation due to cell-to-cell movement of the viral mutant. B, Image taken at the leading edge of a PMTV.YFP- $\Delta$ N84 lesion showing the localization of the YFP- $\Delta$ N84 protein in plasmodesmata (PD) (dart) and the cytoplasm. C, Toward the middle of a PMTV.YFP- $\Delta$ N84 lesion, YFP- $\Delta$ N84 is localized to PD (darts) and the cytoplasm. D, Single overlaid confocal section illustrating YFP- $\Delta$ N84 (green) located in punctate structures (darts) in the cell wall which colocalize with E, aniline-bluestained callose (magenta) in PD. Single confocal sections taken through nuclei showing $\mathbf{F}$, the accumulation of YFP- $\Delta$ N84 (green) in the nucleoplasm and its absence from the nucleolus; G, localization of unfused green fluorescent protein (GFP) in the nucleus but not the nucleolus; H, TGB $1^{1-84}-$ GFP in the nucleoplasm and enriched within the nucleolus. I, Nucleolus in $\mathrm{H}$ is identified by the accumulation of monomeric red fluorescent protein-labeled Arabidopsis fibrillarin 2 (magenta). Bar $=\mathrm{A}, 100 \mu \mathrm{m} ; \mathrm{B}$ and C, $50 \mu \mathrm{m}$; D and E, $10 \mu \mathrm{m} ; \mathrm{F}$ to I, $5 \mu \mathrm{m}$. 
their stabilization (Ashby et al. 2006). The observation that small motile particles labeled with YFP-TGB1 move in association with the ER and that YFP-TGB1 associates with microtubules away from the leading edge of the infection suggest that, as with TMV, cell-to-cell movement of PMTV involves the ER network rather than microtubules. The lack of a significant effect of colchicine or oryzalin on lesion expansion implies that microtubules are not involved in the cell-to-cell movement of the TGB1-labeled viral clone. This is similar to the intercellular movement of a number of other viruses where a role for actin is implicated (Harries et al. 2009), although apparently conflicting results have been reported in these investigations (Harries et al. 2009; Hofmann et al. 2009). Lack of microtubular labeling in the $\Delta \mathrm{N} 84$ mutant is correlated with the lack of TGB1 in the nucleolus and long-distance movement of viral RNA. The TGB $1^{1-84}$-GFP fragment does label the nucleoplasm and nucleolus but does not label microtubules, suggesting that the microtubule-binding domain is elsewhere on the molecule or relies on interaction with other proteins that interact through domains elsewhere on the molecule. It is unclear whether microtubule association is required for translocation of TGB1 to the nucleus, and attempts to use the microtubule-disrupting drug colchicine to investigate this possibility gave inconclusive results (K Wright, unpublished). Therefore, although the data suggest that microtubules are not involved in cell-to-cell movement of PMTV, their precise role requires further investigation.

This is the first report of any TGB protein being associated with the nucleolus, and the finding is surprising for two reasons. First, whereas small proteins of approximate mass up to 40 to $60 \mathrm{kDa}$ or less than approximately $10 \mathrm{~nm}$ in diameter such as GFP or other fluorescent proteins can enter the nucleus passively (Nigg 1997), GFP/YFP-TGB1 is approximately 78 $\mathrm{kDa}$ and, therefore, is unlikely to enter by diffusion. Second, even after entering the nucleus, GFP-TGB1 might be expected to be excluded from the nucleolus (given that the $27-\mathrm{kDa}$ free GFP is excluded) (Hiscox 2002). Cell function is routinely maintained by the regulated traffic of proteins and nucleic acids between the nucleus or nucleolus and the cytoplasm (Yoneda 2000). Peptide motifs rich in the positively charged amino acids arginine and lysine can function as protein nuclear import signals, which can be a simple basic cluster or bipartite signals (Nigg 1997; Mattaj and Englmeier 1998). The PMTV TGB1 sequence contains two motifs within the NTD domain $\left({ }^{9} \underline{R} P \underline{R} \underline{R K D L P D R} \underline{R}^{20}\right.$ and $\left.{ }^{38} \underline{R} T N N N \underline{K K T Q N W} \underline{K P} \underline{R}^{51}\right)$ that may act as nuclear or nucleolar localization signals (Hiscox 2007). Because YFP- $\Delta$ N84 still localizes to the nucleoplasm yet is larger than the predicted size for nuclear pore entry by passive diffusion, it is presumed that there is an additional nuclear localization signal (NLS) elsewhere in the molecule. Therefore, localization of PMTV TGB1 in the nucleolus may reflect an important functional location, possibly by interaction with nucleolar factors. Significantly, in this respect, we have found that PMTV TGB1 interacts with fibrillarin, a major protein component of the nucleolus in vitro (N. O. Kalinina, M. E. Taliansky, and L. Torrance, unpublished results). Fusion of the first $84 \mathrm{~N}$-terminal amino acids of TGB1 to GFP resulted in nucleolar enrichment of GFP which is not seen with free GFP, suggesting that the PMTV TGB1 NTD domain contains a nucleolar localization signal. However, we cannot exclude the possibility that, once inside the nucleus, nucleolar accumulation of TGB1 may also be related to its RNA-binding capacity because the nucleolus is highly enriched in cellular RNAs.

Mutations in the RNA-binding domains in the N-terminal half of the PSLV TGB1 abrogated long-distance movement but not cell-to-cell movement in experiments using a chimeric Hordeivirus sp. in which the BSMV TGB module was re- placed with the mutant PLSV TGB module (Kalinina et al. 2001; Solovyev et al. 1999). Our findings show that the N terminus of PMTV TGB1 is dispensable for local cell-to-cell movement and, in agreement with this, Zamyatnin and associates (2004) reported that deletion of a smaller fragment of the NTD (TGB1-Mlu mutant) did not affect TGB2/TGB3-mediated PD targeting of TGB1. Instead, and similar to PSLV, the $\mathrm{N}$ terminus of PMTV TGB1 is important for systemic virus transport because both an $\mathrm{N}$-terminal deletion and $\mathrm{N}$-terminal fluorescent protein fusions prevented long-distance movement. It is unlikely that this is due to disruptions in TGB1 RNAbinding capacity because, in the presence of RNA ${ }^{\mathrm{CP}}$, PMTV is believed to move in the form of virions that have TGB1 molecules bound to one end via an interaction with the CP-RT product (Torrance et al. 2009). In this vRNP, TGB1 presumably has no direct interaction with the viral RNA. However, the $\triangle \mathrm{N} 84$ mutation prevented systemic virus movement in the presence of RNA ${ }^{\mathrm{CP}}$ (although the $\triangle \mathrm{N} 84$ deletion did not affect the capacity of TGB1 to interact with itself or CP-RT), and systemic movement was also prevented in PMTV.YFP-TGB1, in which all potential RNA-binding domains of TGB1 are intact. Therefore, these results indicate that the $\mathrm{N}$ terminus of TGB1 has a function in long-distance movement that is distinct from both vRNA binding and the interaction with CP-RT, and we postulate that this involves the recruitment of host factors. In this regard, the N-terminally mediated nucleolar localization of the protein may be significant.

Systemic movement of plant viruses through the vasculature requires entry into the sieve element-companion cell complexes of the phloem which comprise a major barrier (Oparka and Turgeon 1999). Phloem entry may require a different mechanism of cell-to-cell transport than local virus movement and interactions with the nucleolus could play a role in this. Targeting of cellular RNAs often requires nuclear factors (Farina and Singer 2002; Bailey-Serres et al. 2009) and a cytoplasmically replicating virus would need special facilities to recruit these. Nuclear factors play a role in the replication cycle of animal and plant RNA viruses (Hiscox 2002, 2007; Gustin and Sarnow 2006; Taliansky et al. in press); for example, proteins of Groundnut rosette virus (GRV) Kim et al. 2004, 2007a and b) and viral genome-linked protein of Potato virus A (PVA) (Rajamaki and Valkonen 2009). Umbravirus spp. such as GRV encode only three proteins (an RNA polymerase and two MPs) and lack a CP, moving long-distance in the vascular system as a vRNP complex (Taliansky and Robinson 2003). The MPs are expressed from overlapping reading frames; ORF4 plays a role in cell-to-cell movement and ORF3 in long-distance movement. ORF3 contains both an NLS and a nuclear export signal (NES) (Ryabov et al. 2004). During a GRV infection, ORF3 traffics to and through the nucleus and nucleolus. In the nucleoplasm, ORF3 of GRV reorganizes cajal bodies into aggregate structures that enter the nucleolus, and subsequent nuclear export of ORF3 leads to a redistribution of the cajal body or nucleolar protein fibrillarin into the cytoplasm, where it forms part of cytoplasmic vRNPs that also contain ORF3 (Kim et al. 2007a and b; Canetta et al. 2008). Mutations which inhibit nucleocytoplasmic shuttling of ORF3 prevent GRV long-distance movement, and the ORF3/fibrillarin-containing cytoplasmic vRNA is believed to be the transport form of the virus (Ryabov et al. 2004; Kim et al. 2007b).

By analogy, it is possible that TGB1 of PMTV (which does not require $\mathrm{CP}$ for long-distance movement) also forms a vRNP that is competent for cell-to-cell movement but is only competent for long-distance movement after passage through the nucleus or nucleolus, where it might acquire host factors necessary for entry to the vasculature (Fig. 7). Interestingly, sequence analysis of PMTV TGB1 using the NES predictor 
indicates that the protein may also have a NES located within its RNA helicase domain. If an interaction of the TGB1 at or near the N-terminal region with an unknown nuclear host factor is required, this could explain why full-length YFP-TGB1 targets the nucleolus but PMTV.YFP-TGB1 does not move systemically, because YFP might obscure such an interaction. A putative role in long-distance movement could also explain why nucleolar localization of TGB1 does not occur at the leading edge of local lesions. Recruitment of nucleolar factors would only be necessary once the virus reaches the mesophyllcompanion cell boundary (Fig. 7), and not during local cell-tocell movement. Mapping studies are currently in progress to identify more precisely the nuclear and nucleolar localization signals and interactions with nuclear components to better understand the mechanism of action.

\section{MATERIALS AND METHODS}

\section{Plasmids.}

Bombardment and binary vectors. Plasmid 35S::mRFPTGB1, which expresses mRFP-TGB1 under the control of the Cauliflower mosaic virus $35 \mathrm{~S}$ promoter, was generated by overlap polymerase chain reaction (PCR). $m R F P$ was amplified from pmRFP1 (Clontech, Palo Alto, CA, U.S.A.) using primers
mRFPNcoFor and p51RevRed (all primers in Supplementary Table S1). TGB1 was amplified from pPMTV3 (Savenkov et al. 2003) using primers p51ForRed and p51XbaRev. The products of these two reactions were combined as template in an overlap extension PCR using primers mRFPNcoFor and p51XbaRev. The final product was cloned into pGEM-T Easy (Promega Corp., Madison, WI, U.S.A.) prior to NcoI/XbaI digestion and subcloning into likewise digested pRTL2 (Restrepo et al. 1990). Plasmid 35S::GFP-TGB1 has been described previously (pRT-GFP-TGBp1) (Zamyatnin et al. 2004).

PMTV cDNA clones. pRNA ${ }^{\mathrm{TGB}}$.YFP-TGB1 was generated from pRNA ${ }^{\mathrm{TGB}}$.GFP-TGB1 (Zamyatnin et al. 2004) by replacing the NcoI-flanked GFP ORF with YFP amplified with primers eYFP-NcoI-N eYFP-BamHI-NcoI. A TGB1 deletion mutant lacking the $\mathrm{N}$-terminal 84 aa $(\triangle \mathrm{N} 84)$ was amplified from pPMTV3 with primers RNA-TGB-KpnI-neg and PMTP1-84-minus-Nco. The NcoI/KpnI-digested PCR product was cloned into the same sites of pRNA ${ }^{\mathrm{TGB}}$.GFP-TGB1, replacing both $G F P$ and full-length $T G B 1$ and yielding pRNA-TGB. $\triangle \mathrm{N} 84$. $\mathrm{pRNA}^{\mathrm{TGB}}$.YFP- $\triangle \mathrm{N} 84$ was constructed by cloning $Y F P$ into $N$ coI-digested $\mathrm{pRNA}^{\mathrm{TGB}} . \Delta \mathrm{N} 84$.

GFP-fusion of the N-terminal residues. A GFP-fusion of the $\mathrm{N}$-terminal 84 residues of TGB1 was constructed by amplifying the respective portion of the TGB1 ORF from pPMTV3

\section{TGB1 FL-Clone}

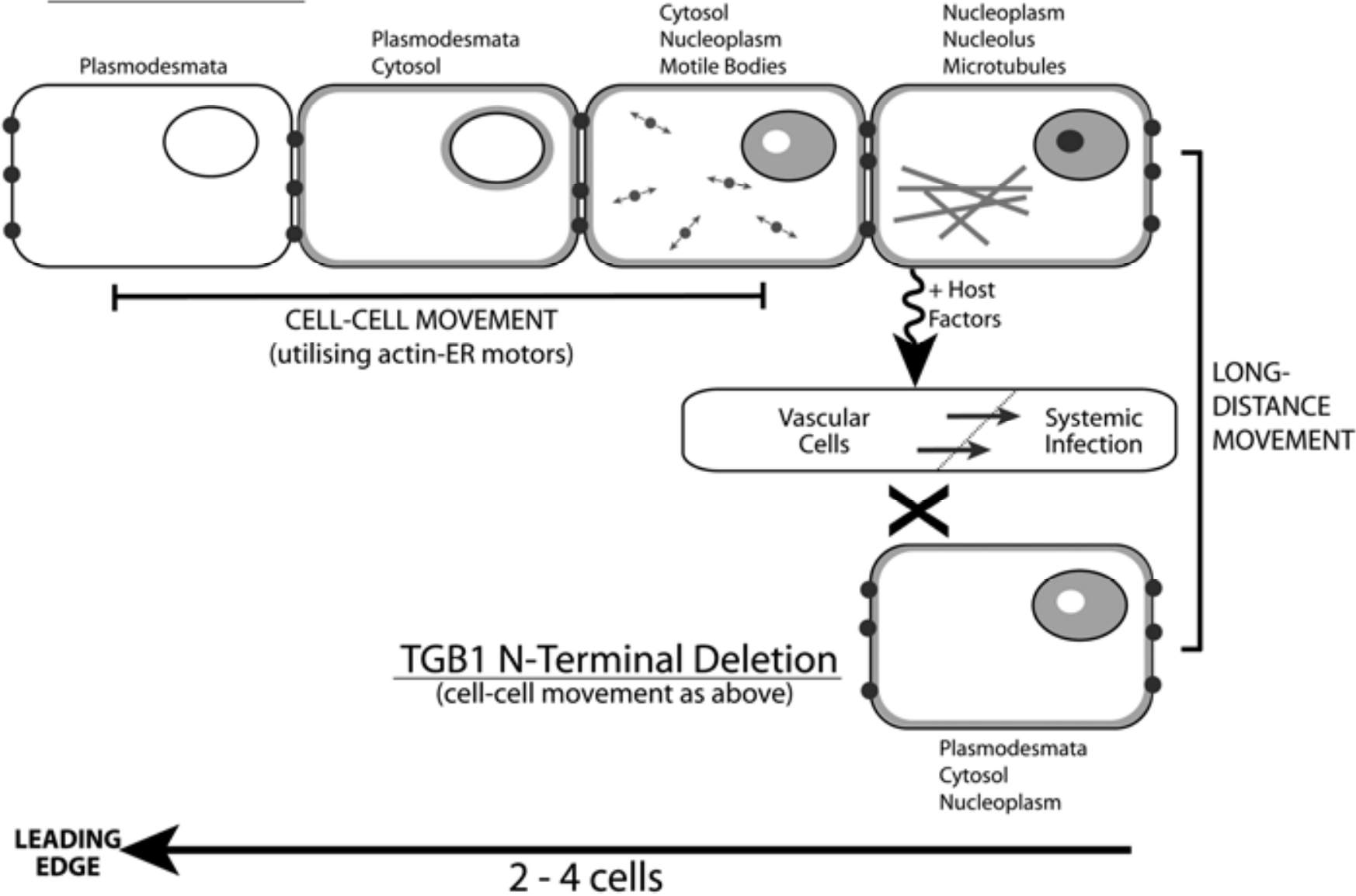

Fig. 7. Diagram depicting localizations of full-length (FL) triple-gene-block (TGB)1 (top) and the N-terminal deletion mutant $\Delta$ N84 (bottom) at the leading edge of an expanding Potato mop-top virus (PMTV) lesion as inferred from observations with fluorescent protein fusions. The results suggest a model with two distinct stages of viral movement. i) Cell-to-cell movement involves the viral nucleoprotein complex (vRNP, comprising TGB1 and viral RNA) moving intracellularly on endoplasmic reticulum-actin motors to access the plasmodesmata (PD) and move to neighboring cells; some TGB1 remains in the PD pore. ii) Long-distance movement of vRNP requires passage of TGB1 through the nucleolus with the possible involvement of microtubules. Nucleolar passage is necessary to acquire host factors or modification to enable access to the vascular system and occurs slightly later than intercellular movement processes, one or two cells behind the leading edge. Although, for clarity, we have drawn the localizations in a linear order over four cells, we believe that the movement processes occur rapidly and nucleolar and microtubule labeling has been observed within one cell from the visible leading edge. 
with Gateway attB adapters and recombining the PCR product into pDONR207 using Gateway BP Clonase II (Invitrogen, Carlsbad, CA, U.S.A.). The donor plasmid insert was sequenced and recombined into the destination vector pGWB405 for Cterminal fusion to GFP (Nakagawa et al. 2007) using Gateway LR Clonase II.

Yeast two-hybrid plasmids. Yeast expression vectors were generated using the pLex-Na and pVP16+ vectors (Hollenberg et al. 1995). pLex-CP-RT, pVP16-CP-RT, pLex-TGB1, and pVP16-TGB1 have been described previously (Cowan et al. 2002; Torrance et al. 2009). TGB1 N-terminal deletion mutants were amplified from pPMTV3 with primer pairs YTHSBam-N-ter-84aa/YTHS-Sal-C-ter-P1 or YTHS-Apa-N-ter-84aa/ YTHS-Bam-C-ter-P1, respectively. BamHI/SalI- or BamHI/ ApaI-digested PCR products were ligated into the same sites of pLex-Na or pVP16+, respectively. The resulting constructs are referred to as pLex- $\Delta \mathrm{N} 84$ and $\mathrm{pVP} 16-\Delta \mathrm{N} 84$.

\section{Yeast two-hybrid assays.}

The interaction between Lex A and VP16 fusion proteins was examined in Saccharomyces cerevisiae L40 as described previously (Cowan et al. 2002).

\section{Plant material and inoculations.}

$N$. benthamiana and transgenic plants were grown from seed and maintained under glasshouse conditions with a day length of $16.5 \mathrm{~h}$, minimum daytime temperature of $28^{\circ} \mathrm{C}$, and minimum night-time temperature of $22^{\circ} \mathrm{C}$. Supplementary lighting was provided below a daytime threshold of $250 \mathrm{~W} \mathrm{~m}^{-2}$ and sun screening was used above $400 \mathrm{~W} \mathrm{~m}^{-2}$. Plants were used for experiments when they were 30 to 35 days old. The following transgenic plants were used: $N$. benthamiana plants expressing a fusion of GFP to Arabidopsis $\alpha$-tubulin (TUA-GFP) as described previously (Gillespie et al. 2002) and ER-GFP N. benthamiana plants expressing mGFP5-ER, kindly provided by D Baulcombe (Ruiz et al. 1998).

Infectious PMTV RNA in vitro transcripts were synthesized from pPMTV1 (MluI-linearized), pPMTV2 (= pRNA $\left.{ }^{\mathrm{CP}}\right)$, and pPMTV3 (=pRNA ${ }^{\mathrm{TGB}}$ ) (Savenkov et al. 2003) or its derivatives (all SpeI-linearized), using the mMessage mMachine $\mathrm{T} 7 \mathrm{kit}$ (Ambion, Austin, TX, U.S.A.) following the manufacturer's instructions. Mixtures of infectious transcripts are collectively referred to as PMTV.YFP-TGB1 and so on. Transcripts were mixed with GKP buffer ( $50 \mathrm{mM}$ glycine, $30 \mathrm{mM} \mathrm{K} \mathrm{HPO}_{4}[\mathrm{pH}$ 9.4], $1 \%$ bentonite, and $1 \%$ celite) and mechanically inoculated onto $N$. benthamiana plants. Following inoculation with viral transcript, plants were maintained in a controlled environment cabinet at $22^{\circ} \mathrm{C}$ with a 16 -h day and 8 -h night and imaged after 4 days unless otherwise stated.

$35 \mathrm{~S}$ plasmid constructs were introduced into epidermal cells of $N$. benthamiana by biolistic bombardment using a hand gun, essentially as described by Gal On and associates (1997). Bombarded plants were kept at $22^{\circ} \mathrm{C}$ and imaged after 1 to 3 days.

Binary expression vectors 35S::Arabidopsis thaliana fibrillarin 2 (AtFib2)-mRFP (Kim et al. 2007b) and pGWB405 derivatives were electroporated into Agrobacterium tumefaciens GV3101 or LBA4404 and infiltrated into N. benthamiana leaves as described by Latijnhouwers and associates (2005). For AtFib2-mRFP colocalizations, $N$. benthamiana plants were infected with either PMTV.YFP-TGB1 or PMTV.YFP- $\triangle$ N84 and, 7 days later, were infiltrated with 35S::AtFib2-mRFP agrobacteria (optical density at $600 \mathrm{~nm}=0.1$ ) and maintained for 4 days at $22^{\circ} \mathrm{C}$ until imaged (i.e., day 11 after virus infection).

\section{Confocal microscopy.}

All imaging was conducted using a Leica TCS-SP2 AOBS fitted with a motorized stage to allow precise relocation (Leica
Microsystems GmbH, Heidelberg, Germany). Unless otherwise stated, images were obtained using a Leica HCX APO x63/0.9W water-dipping lens and whole lesions using a HCX PL Fluotar $\times 1.6 / 0.05$ lens; GFP and YFP were imaged sequentially: GFP excitation $488 \mathrm{~nm}$, emission 490 to $510 \mathrm{~nm}$; YFP excitation $514 \mathrm{~nm}$, emission 535 to $545 \mathrm{~nm}$. GFP and mRFP were imaged sequentially: GFP excitation $488 \mathrm{~nm}$, emission 500 to $530 \mathrm{~nm}$; mRFP excitation $561 \mathrm{~nm}$, emission 590 to 630 $\mathrm{nm}$. Unless otherwise stated, images are maximum-intensity projections of multiple-layered stacks. Images were assembled and edited using Adobe Photoshop CS version 8.0.

\section{Aniline blue staining of callose in PD.}

Leaf tissue was infiltrated with a $0.01 \%$ (wt/vol) solution of aniline blue (VWR, Lutterworth, U.K.) in 0.07 M Sorensens phosphate buffer, $\mathrm{pH}$ 7.5. Infection sites were imaged by sequential scanning at $405 \mathrm{~nm}$ excitation, 480 to $510 \mathrm{~nm}$ emission for aniline blue and $514 \mathrm{~nm}$ excitation, 535 to $545 \mathrm{~nm}$ emission for YFP.

\section{Inhibitor treatments.}

Effect of inhibitors on microtubules. Leaf tissue was infiltrated with $500 \mu \mathrm{M}$ colchicine or $57 \mu \mathrm{M}\left(20 \mu \mathrm{g} \mathrm{ml}^{-1}\right)$ oryzalin to disrupt microtubules, or the appropriate solvent control as described previously (Wright et al. 2007). When imaged within 30 min of infiltration, there was no effect on microtubule structure (data not shown).

Effect of inhibitors on lesion expansion. Intact leaves from the same position in four plants were inoculated with PMTV.YFP-TGB1 and incubated for 4 days. Initial trials indicated that lesion expansion was significantly different between leaves regardless of inhibitor and, therefore, one leaf per plant was split in two at the midrib for each of the inhibitors. The detached split leaves were infiltrated with either an inhibitor or the appropriate control solution and mounted on double-sided adhesive tape on a microscope slide. Lesions were located and imaged as described above within $30 \mathrm{~min}$ of infiltration and then after $48 \mathrm{~h}$ of incubation in contact with tissue moistened with inhibitor. Lesion area was measured using the measure tool in Image Pro Plus (version 4.1; Media Cybernetics). Area measurements were log transformed to normalize the data. Change in lesion area between the two time points were compared for each leaf control and inhibitor using a two-sample $t$ test assuming unequal variance.

\section{ACKNOWLEDGMENTS}

We thank M. E. Taliansky for providing us with AtFib; and the Scottish Government Rural and Environmental Research and Analysis Directorate (to K. M. Wright, G. H. Cowan, J. Tilsner, A. G. Roberts, and L. Torrance); the Swedish Research Council for Environment, Agricultural Sciences and Spatial Planning (Formas, grant 2008-1047); the Carl Tryggers Foundation; the Swedish Institute (post-doctoral stipend for N. I. Lukhovitskaya); and the Wenner-Gren Foundations, Stockholm (sabbatical stipend for E. I. Savenkov to carry out a program of scientific research at Scottish Crop Research Institute) for their financial support.

\section{LITERATURE CITED}

Adams, M. J., Antoniw, J. F., and Kreuze, J. 2009. Virgaviridae: A new family of rod-shaped plant viruses. Arch. Virol. 154:1967-1972.

Ashby, J., Boutant, E., Seemanpillai, M., Sambade, A., Ritzenthaler, C., and Heinlein, M. 2006. Tobacco mosaic virus movement protein functions as a structural microtubule-associated protein. J. Virol. 80:83298344.

Bailey-Serres, J., Sorenson, R., and Juntawong, P. 2009. Getting the message across: Cytoplasmic ribonucleoprotein complexes. Trends Plant Sci. 14:443-453.

Barneche, F., Steinmetz, F., and Echeverria, M. 2000. Fibrillarin genes encode both a conserved nucleolar protein and a novel small nucleolar 
RNA involved in ribosomal RNA methylation in Arabidopsis thaliana. J. Biol. Chem. 275:27212-27220.

Bleykasten, C., Gilmer, D., Guilley, H., Richards, K. E., and Jonard, G. 1996. Beet necrotic yellow vein virus $42 \mathrm{kDa}$ triple gene block protein binds nucleic acid in vitro. J. Gen. Virol. 77:889-897.

Canetta, E., Kim, S. H., Kalinina, N. O., Shaw, J., Adya, A. K., Gillespie, T., Brown, J. W. S., and Taliansky, M. 2008. A plant virus movement protein forms ring-like complexes with the major nucleolar protein, fibrillarin, in vitro. J. Mol. Biol. 376:932-937.

Cowan, G. H., Lioliopoulou, F., Ziegler, A., and Torrance, L. 2002. Subcellular localisation, protein interactions, and RNA binding of Potato mop-top virus triple gene block proteins. Virology 298:106-115.

Donald, R. G., Lawrence, D. M., and Jackson, A. O. 1997. The barley stripe mosaic virus 58 -kilodalton $\beta$ b protein is a multifunctional RNA binding protein. J. Virol. 71:1538-1546.

Erhardt, M., Herzog, E., Lauber, E., Fritsch, C., Guilley, H., Jonard, G., Richards, K., and Bouzoubaa, S. 1999. Transgenic plants expressing the TGB1 protein of peanut clump virus complement movement of TGB1defective peanut clump virus but not of TGB1-defective beet necrotic yellow vein virus. Plant Cell Rep. 18:614-619.

Erhardt, M., Morant, M., Ritzenthaler, C., Stussi-Garaud, C., Guilley, H., Richards, K., Jonard, G., Bouzoubaa, S., and Gilmer, D. 2000. P42 movement protein of Beet necrotic yellow vein virus is targeted by the movement proteins P13 and P15 to punctate bodies associated with plasmodesmata. Mol. Plant-Microbe Interact. 13:520-528.

Farina, K. L., and Singer, R. H. 2002. The nuclear connection in RNA transport and localization. Trends Cell Biol. 12:466-472.

Gal On, A., Meiri, E., Elman, C., Gray, D. J., and Gaba, V. 1997. Simple hand-held devices for the efficient infection of plants with viral-encoding constructs by particle bombardment. J. Virol. Methods 64:103110 .

Gillespie, T., Boevink, P., Haupt, S., Roberts, A. G., Toth, R., Valentine, T. A., Chapman, S., and Oparka, K. J. 2002. Functional analysis of a DNA-shuffled movement protein reveals that microtubules are dispensable for the cell-to-cell movement of Tobacco mosaic virus. Plant Cell 14:1207-1222.

Gustin, K. E., and P. Sarnow. 2006. Positive-strand RNA viruses and the nucleus. Pages 161-184 in: Viruses and the Nucleus. J. A. Hiscox, ed. John Wiley and Sons Ltd.

Harries, P. A., Park, J. W., Sasaki, N., Ballard, K. D., Maule, A. J., and Nelson, R. S. 2009. Differing requirements for actin and myosin by plant viruses for sustained intercellular movement. Proc. Natl. Acad. Sci. U.S.A. 106:17594-17599.

Hiscox, J. A. 2002. The nucleolus - a gateway to viral infection? Arch Virol. 147:1077-1089.

Hiscox, J. A. 2007. RNA viruses: Hijacking the dynamic nucleolus. Nat. Rev. Microbiol. 5:119-127.

Hofmann, C., Niehl, A., Sambade, A., Steinmetz, A., and Heinlein, M. 2009. Inhibition of Tobacco mosaic virus movement by expression of an actin-binding protein. Plant Physiol. 149:1810-1823.

Hollenberg, S. M., Sternglanz, R., Cheng, P. F., and Weintraub, H. 1995. Identification of a new family of tissue specific basic helix-loop proteins with a two-hybrid system. Mol. Cell Biol. 15:3813-3822.

Hsu, H. T., Tseng, Y. H., Chou, Y. L., Su, S. H., Hsu, Y. H., and Chang, B. Y. 2009. Characterization of the RNA-binding properties of the triplegene-block protein 2 of Bamboo mosaic virus. Virol. J. 6:50.

Jackson, A. O., Lim, H. S., Bragg, J., Ganesan, U., and Lee, M. Y. 2009. Hordeivirus replication, movement, and pathogenesis. Annu. Rev. Phytopathol. 47:385-422.

Kalinina, N. O., Rakitina, D. A., Yelina, N. E., Zamyatnin, A. A., Jr., Stroganova, T. A., Klinov, D. V., Prokhorov, V. V., Ustinova, S. V., Chernov, B. K., Schiemann, J., Solovyev, A. G., and Morozov, S. Y. 2001. RNA-binding properties of the $63 \mathrm{kDa}$ protein encoded by the triple gene block of poa semilatent hordeivirus. J. Gen. Virol. 82:25692578

Kalinina, N. O., Rakitina, D. V., Solovyev, A. G., Schiemann, J., and Morozov, S. Y. 2002. RNA helicase activity of the plant virus movement proteins encoded by the first gene of the triple gene block. Virology 296:321-329.

Kim, S. H., Ryabov, E. V., Brown, J. W. S., and Taliansky, M. 2004. Involvement of the nucleolus in plant virus systemic infection. Biochem. Soc. Trans. 32:557-560

Kim, S. H., MacFarlane, S., Kalinina, N. O., Rakitina, D. V., Ryabov, E. V., Gillespie, T., Haupt, S., Brown, J. W. S., and Taliansky, M. 2007a. Interaction between a plant virus-encoded protein and the major nucleolar protein, fibrillarin, is required for systemic infection. Proc. Natl. Acad. Sci. U.S.A. 104:11115-11120.

Kim, S. H., Ryabov, E. V., Kalinina, N. O., Rakitina, D. V., Gillespie, T., MacFarlane, S. A., Haupt, S., Brown, J. W. S., and Talianksy, M. E. 2007b. Cajal bodies and the nucleolus are required for a plant virus sys- temic infection. EMBO (Eur. Mol. Biol. Organ.) J. 26:2169-2179.

Latijnhouwers, M., Hawes, C., Carvalho, C., Oparka, K., Gillingham, A. K., and Boevink, P. 2005. An Arabidopsis GRIP domain protein locates to the trans-Golgi and binds the small GTPase ARL1. Plant J. 44:459470 .

Lawrence, D. M., and Jackson, A. O. 2001. Interactions of the TGB1 protein during cell-to-cell movement of Barley stripe mosaic virus. J. Virol. 75:8712-8723.

Leshchiner, A. D., Solovyev, A. G., Morozov, S. Y., and Kalinina, N. O. 2006. A minimal region in the NTPase/helicase domain of the TGBp1 plant virus movement protein is responsible for ATPase activity and cooperative RNA binding. J. Gen. Virol. 87:3087-3095.

Lim, H. S., Bragg, J. N., Ganesan, U., Lawrence, D. M., Yu, J. L., Isogai, M., Hammond, J., and Jackson, A. O. 2008. Triple gene block protein interactions involved in movement of Barley stripe mosaic virus. J. Virol. 82:4991-5006.

Lim, H. S., Bragg, J. N., Ganesan, U., Ruzin, S., Schichnes, D., Lee, M. Y., Vaira, A. M., Ryu, K. H., Hammond, J., and Jackson, A. O. 2009. Subcellular localization of the Barley stripe mosaic virus triple gene block proteins. J. Virol. 83:9432-9448.

Makarov, V., Rybakova, E., Efimov, A., Dobrov, E., Serebryakova, M., Solovyev, A., Yaminsky, I., Taliansky, M., Morozov, S., and Kalinina, N. 2009. Domain organization of the $\mathrm{N}$-terminal portion of hordeivirus movement protein TGBp1. J. Gen. Virol. 90:3022-3032.

Mattaj, I. W., and Englmeier, L. 1998. Nucleocytoplasmic transport: The soluble phase. Annu. Rev. Biochem. 67:265-306.

Morozov, S. Y., and Solovyev, A. G. 2003. Triple gene block: Modular design of a multifunctional machine for plant virus movement. J. Gen. Virol. 84:1351-1366.

Nakagawa, T., Kurose, T., Hino, T., Tanaka, K., Kawamukai, M., Niwa, Y., Toyooka, K., Matsuoka, K., Jinbo, T., and Kimura, T. 2007. Development of series of gateway binary vectors, pGWBs, for realizing efficient construction of fusion genes for plant transformation. J. Biosci. Bioeng. 104:34-41.

Nigg, E. A. 1997. Nucleocytoplasmic transport: Signals, mechanisms and regulation. Nature 386:779-787.

Oparka, K. J., and Turgeon, R. 1999. Sieve elements and companion cells-traffic control centers of the phloem. Plant Cell 11:739-750.

Rajamaki, M. L., and Valkonen, J. P. T. 2009. Control of nuclear and nucleolar localization of nuclear inclusion protein a of Picorna-like Potato virus A in Nicotiana species. Plant Cell 21:2485-2502.

Restrepo, M. A., Freed, D. D., and Carrington, J. C. 1990. Nuclear transport of plant potyviral proteins. Plant Cell 2:987-998.

Ruiz, M. T., Voinnet, O., and Baulcombe, D. C. 1998. Initiation and maintenance of virus-induced gene silencing. Plant Cell 10:937-946.

Ryabov, E. V., Kim, S. H., and Taliansky, M. 2004. Identification of a nuclear localization signal and nuclear export signal of the umbraviral long-distance RNA movement protein. J. Gen. Virol. 85:1329-1333.

Savenkov, E. I., Germundsson, A., Zamyatnin, A. A., Sandgren, M., and Valkonen, J. P. T. 2003. Potato mop-top virus: The coat protein-encoding RNA and the gene for cysteine-rich protein are dispensable for systemic virus movement in Nicotiana benthamiana. J. Gen. Virol. 84:1001-1005

Solovyev, A. G., Savenkov, E. I., Grdzelishvili, V. Z., Kalinina, N. O., Morozov, S. Y., Schiemann, J., and Atabekov, J. G. 1999. Movement of hordeivirus hybrids with exchanges in the triple gene block. Virology 253:278-287.

Solovyev, A. G., Stroganova, T. A., Zamyatnin, A. A., Fedorkin, O. N., Schiemann, J., and Morozov, S. Y. 2000. Subcellular sorting of small membrane-associated triple gene block proteins: TGBp3-assisted targeting of TGBp2. Virology 269:113-127.

Taliansky, M. E., and Robinson, D. J. 2003. Molecular biology of umbraviruses: Phantom warriors. J. Gen. Virol. 84:1951-1960.

Taliansky, M. E., Brown, J. W. S., Rajamaki, M. L., Valkonen, J., and Kalinina, N. O. Involvement of the plant nucleolus in virus and viroid infections; parallels with animal pathosystems. Adv. Virus Res. In press.

Tilsner, J., Cowan, G. H., Roberts, A. G., Chapman, S. N., Ziegler, A., Savenkov, E., and Torrance, L. Plasmodesmal targeting and intercellular movement of potato mop-top pomovirus is mediated by a membrane anchored tyrosine-based motif on the lumenal side of the endoplasmic reticulum and the $\mathrm{C}$-terminal transmembrane domain in the TGB3 movement protein. Virology 402:41-51.

Torrance, L. 2008. Pomoviruses. In: Encyclopedia of Virology. B. W. J. Mahy and M. H. V. Van Regenmortel, eds. Academic Press, Elsevier.

Torrance, L., Lukhovitskaya, N. I., Schepetilnikov, M. V., Cowan, G. H., Ziegler, A., and Savenkov, E. I. 2009. Unusual long-distance movement strategies of Potato mop-top virus RNAs in Nicotiana benthamiana. Mol. Plant-Microbe Interact. 22:381-390.

Verchot-Lubicz, J. 2005. A new cell-to-cell transport model for Potexvi- 
ruses. Mol. Plant-Microbe Interact. 18:283-290.

Wright, K. M., Wood, N. T., Roberts, A. G., Chapman, S., Boevink, P. MacKenzie, K. M., and Oparka, K. J. 2007. Targeting of TMV movement protein to plasmodesmata requires the actin/ER network; evidence from FRAP. Traffic 8:21-31.

Yoneda, Y. 2000. Nucleocytoplasmic protein traffic and its significance to cell function. Genes Cells 5:777-787.

Zamyatnin, A. A., Solovyev, A. G., Sablina, A. A., Agranovsky, A. A. Katul, L., Vetten, H. J., Schiemann, J., Hinkkanen, A. E., Lehto, K., and Morozov, S. Y. 2002. Dual-colour imaging of membrane protein targeting directed by Poa semilatent virus movement protein TGBp3 in plant and mammalian cells. J. Gen. Virol. 83:651-662.

Zamyatnin, A. A., Solovyev, A. G., Savenkov, E. I., Germundsson, A., Sandgren, M., Valkonen, J. P. T., and Morozov, S. Y. 2004. Transient coexpression of individual genes encoded by the triple gene block of Potato mop-top virus reveals requirements for TGBp1 trafficking. Mol. Plant-Microbe Interact. 17:921-930.

\section{AUTHOR-RECOMMENDED INTERNET RESOURCE}

Center for Biological Sequence Analysis NES predictor: www.cbs.dtu.dk 